\title{
The effect of sulfide and an increased food supply on the meiofauna and macrofauna at the East Flower Garden brine seep
}

\author{
E. N. Powell, T. J. Bright \& J. M. Brooks \\ Department of Oceanography, Texas A \& M University; College Station, TX 77843, USA
}

\begin{abstract}
A sulfurous brine seep at the East Flower Garden Bank, northwest Gulf of Mexico, produces conditions conducive to the growth of a luxuriant prokaryotic biota. Hydrodynamic cropping continually harvests this biota and distributes it to sandy-bottom and hard-bank benthic communities downstream of the seep. Consequently, both macro- and meiofaunal abundances are dramatically increased above the regional norm in parts of the seep system. When sulfide is present, the lower Bilaterian groups belonging to the meiofauna dominate the community; without sulfide, macrofaunal groups, particularly crustaceans, dominate the community. Outside the influence of the seep, meiofaunal copepods predominate. Changes in taxonomic composition and abundance indicate that the sandy-bottom benthos at $70-80 \mathrm{~m}$ depth at the East Flower Garden bank is foodlimited and that, under these conditions, meiofauna, particularly the higher Bilaterian groups, dominate the community numerically. Perhaps, under food-limiting conditions, meiofauna compete favorably with macrofauna for food.
\end{abstract}

\section{INTRODUCTION}

The effect of food supply on community composition of otherwise more or less identical habitats is of long-standing importance in benthic ecology and has received renewed interest following the discovery of relatively food-rich oases in areas such as geothermal vents (Enright et al., 1981; Ballard \& Grassle, 1979; Comita et al., 1984) and hydrocarbon and brine seeps (Stein, 1984; Spies \& Davis, 1979; Powell et al., 1983). These studies have confirmed the general belief of food limitation in the deep sea and suggested food limitation on the continental shelf. Even in supposedly food-rich estuaries, some effects of restricted food supply are well described (Peterson, 1982; 1983), although a community-wide limitation may not exist (Dauer et al., 1982; Wiltse et al., 1984). A brine seep at the East Flower Garden Bank provides an opportunity to examine the importance of food availability in structuring communities of the continental shelf. In this paper, we first review the ecologic setting at the East Flower Garden (EFG) brine seep, then discuss the faunal distribution patterns in the adjacent communities and the evidence for an increased food supply produced by the brine seep's microbiota. Finally, we discuss the effect of this change in food supply on community structure and consider the relationship between meiofauna and macrofauna in benthic communities under food-limiting conditions. 


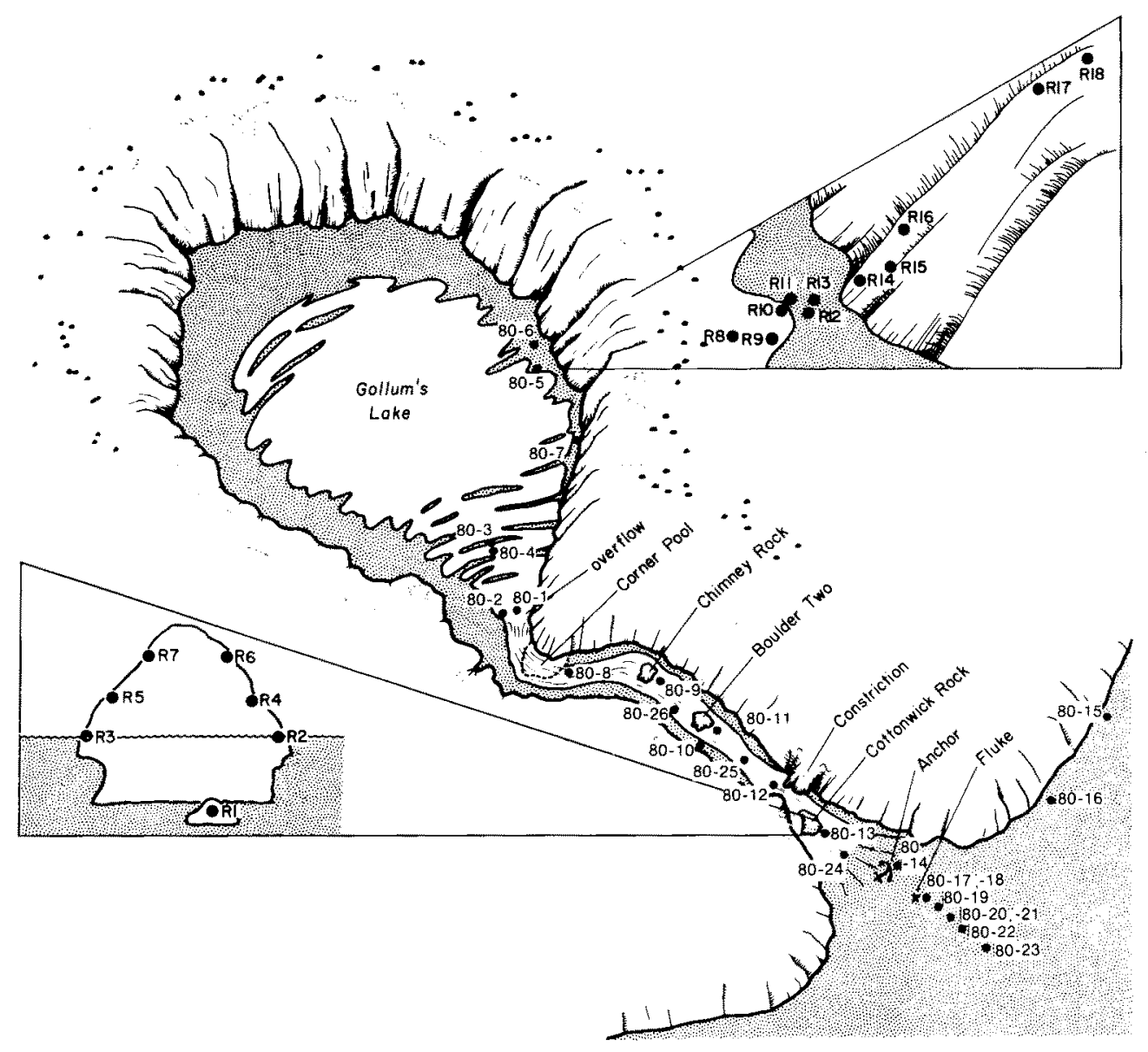

Fig. 1. Location of collection sites on the sandy-bottom and hard-bottom at the East Flower Garden brine seep. For clarity in locating the stations, the canyon width and height and size of boulders is exaggerated. Canyon length and lake dimensions are drawn to scale. Distance from Overflow to Canyon mouth is $96 \mathrm{~m}$. Additional dimensions are described in the text

\section{MATERIALS AND METHODS}

Most methods for collection and sample analysis were described by Powell et al. (1983) and Gittings et al. (1984), as were detailed site descriptions. Sampling locations and terminology are shown in Figure 1.

Samples for carbon isotope analyses were frozen immediately after collection on pre-ashed glass fiber filters and kept frozen until analysis. Prior to analysis, each sample was treated with dilute $\mathrm{HCl}$ to remove inorganic carbon. The remaining carbon was analyzed by the method of Sackett et al. (1970). Data are reported in terms of $\delta^{13} \mathrm{C}$ in parts-per-thousand relative to the PDB standard (Fry et al, 1984). 
Cluster analyses were performed using an unweighted pair-group-clustering method with Euclidean distance as the similarity index. Data were log-transformed prior to analysis.

\section{EFG BRINE SEEP: ECOLOGIC SETTING}

Brine, produced from dissolution of a salt dome underlying the EFG bank, flows into an amphitheatre-shaped basin at about $72 \mathrm{~m}$ depth near the edge of the bank. A brine lake (Gollum's Lake), approximately $25 \mathrm{~cm}$ deep, occupies the slightly lower eastern and central basin floor. Large sand waves occur in the lake, probably formed during the passage of major storms. Brine spills out of the lake at an overflow forming a brine stream which runs along the axis of a canyon (Gollum's Canyon), approximately $10 \mathrm{~m}$ wide at the bottom, $15 \mathrm{~m}$ wide at the top, $96 \mathrm{~m}$ in length, and extending from the eastsoutheast margin of the basin to the edge of the bank at $79 \mathrm{~m}$ depth. A small pool (Corner Pool), in a depression $2 \mathrm{~m}$ downstream from the overflow, contains undiluted brine and may represent a secondary seepage of brine from the substratum at a level slightly below the main seep.

Chemical aspects of the East Flower Garden brine were reported by Brooks et al. (1979). Bright et al. (1980a), and Powell et al. (1983). The brine is denser than seawater, anoxic, and contains exceptionally high levels of dissolved hydrocarbon gases (methane, ethane, and propane) and hydrogen sulfide. The density differential inhibits mixing of lake brine with overlying seawater, although diffusion of dissolved components does occur. Because of the lack of mixing, chemical characteristics of water above and below the interface differ drastically over a vertical distance of less than $2 \mathrm{~cm}$ (e. g. salinity approximately $36 \%$ vs. $200 \%$ ) (Fig. 2).

Gollum's Lake contains about $465 \mathrm{~m}^{3}$ of brine. The overflow rate of brine from the lake into the canyon was estimated to be 355 to $718 \mathrm{~m}^{3} /$ day, yielding a residence time of 0.65 to 1.3 days. Mixing of the brine with overlying seawater starts immediately as the

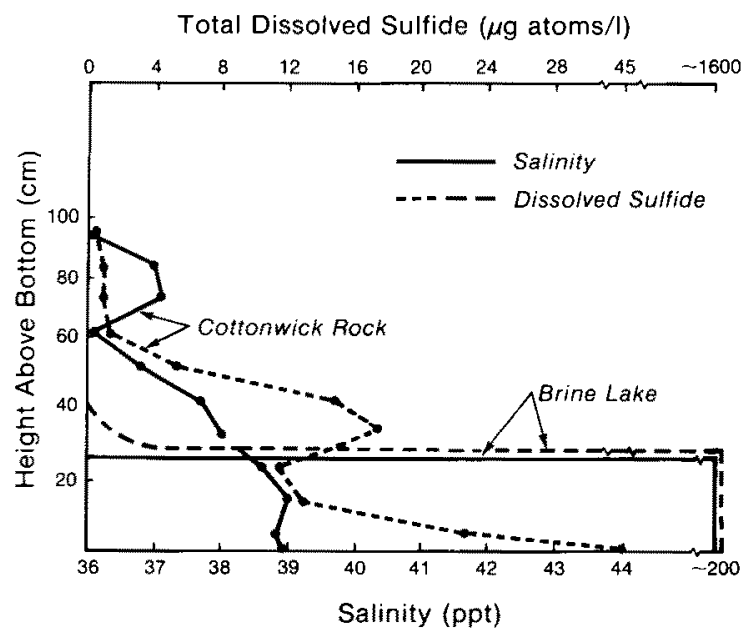

Fig. 2. Vertical gradients in salinity and sulfide from Gollum's Lake and Gollum's Canyon near Cottonwick Rock 
brine spills out of the lake into the canyon, down a $0.5 \mathrm{~m}$ fall. Due to entrainment of increasing amounts of seawater in the downstream direction, the volume of recognizable brine is considerably greater at the canyon mouth (stream $1.0 \mathrm{~m}$ thick) than it is near the lake overflow (stream $0.3 \mathrm{~m}$ thick). At the canyon mouth the brine stream leaves its channel, spreads laterally, decreases substantially in height, and dissipates as it moves onto the level bottom adjacent to the bank.

Salinity and total dissolved sulfide in the brine stream decrease considerably at two places during the stream's travel down the canyon: one in the overflow between Gollum's Lake and Corner Pool and the second between a downstream narrowing of the canyon (Constriction) and the Anchor, in the vicinity of Cottonwick Rock. Salinity in the overflow was $55 \%$, down from $200 \%$ in Gollum's Lake. Near mid-canyon, salinity was $40-42 \%$, and near the canyon mouth, 37 to $40 \%$.

Total dissolved sulfide in 1980 was $1607 \mu \mathrm{M}$ in the lake. This is distinctly lower than the value obtained by Brooks et al. (1979) and suggests a greater year to year variability in sulfide concentration than in salt concentration. In the canyon, sulfide concentration varied from $80 \mu \mathrm{M}$ just downstream of Corner Pool to $32 \mu \mathrm{M}$ at the Anchor. Salinity and sulfide dropped to values near regional norms just below the canyon mouth.

Fine sands $\leq 0.25-0.063 \mathrm{~mm}$

Very coarse to medium sands $=2.0-0.25 \mathrm{~mm}$

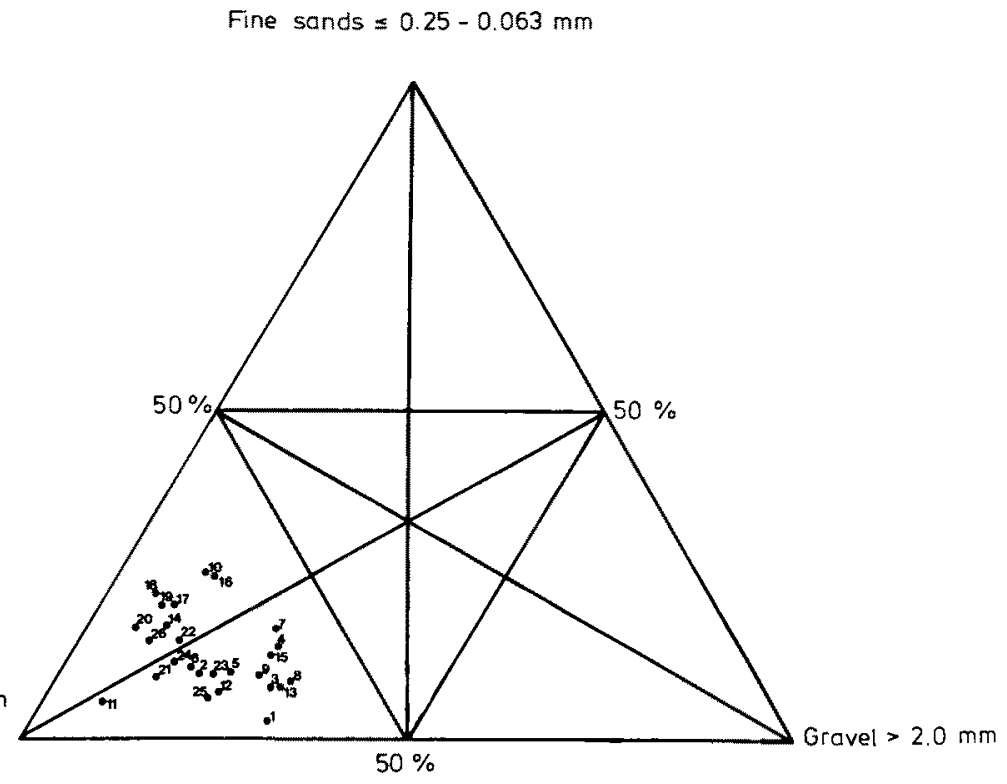

Fig. 3. Sediment texture at the sandy-bottom stations sampled at the East Flower Garden brine seep

Brine flows at a rate of 10 to $25 \mathrm{~cm} / \mathrm{sec}$ down the canyon axis. The travel time for water down the canyon is $15 \mathrm{~min}$, sufficiently fast to make physical oxidation insignificant, even with substantial quantities of oxygen available, because of the slow rate at which sulfide is oxidized relative to the hydrodynamics involved (O'Brien \& Birkner, 1977; Cline \& Richards, 1969). Consequently, dilution is the only significant factor controlling sulfide concentration (and salinity) in the canyon. Salinity and sulfide 
concentration also decrease from the bottom to the top of the brine stream (Fig. 2), but contain many local heterogeneities which are probably manifestations of the dynamic mixing associated with the brine stream.

Most sediments at the EFG brine seep are very coarse to granular sands, and poorly sorted. Sediment grain sizes are quite uniform over the entire area, being slightly coarser in the canyon and around Gollum's Lake, slightly finer below Cottonwick Rock and just downstream of the canyon mouth, and intermediate at the farthest downstream stations (Fig. 3).

Scour and erosional undercutting of carbonate rock is apparent where large boulders occur in the stream or where the stream contacts the canyon wall. The sand and rubble substratum of the canyon has also been affected by the flow. In 1976, coarse carbonate sand had been piled in levee-like deposits on either side of the stream channel and along the base of the canyon walls. By contrast, in 1980 the channel contained large ripple marks and showed evidence of substantial flushing and sediment transport. Sand waves were much larger that year in Gollum's Lake as well. We surmise that passage of Hurricane Allen near the EFG bank in August, 1980 was responsible for these effects (e. g. Brooks, 1983).

\section{BIOTA}

\section{Microflora}

White patches were observed floating at the brine-seawater interface of Gollum's Lake and adhering to the substratum everywhere the interface intersected the bottom. Sulfide-oxidizing mixotrophic bacteria, isolated from the 1977 East Flower Garden brine samples, produced sulfur deposits in the laboratory (Lauer, 1979). Evidence strongly indicates, therefore, that the white material at the lake's interface is produced by a planktonic population of sulfur bacteria living just above the lake's surface.

A narrow, dark-olive colored mat typically occurs directly beneath and bordering the white mats in the lake. Deeper in the brine, covering nearly all of the bottom of the lake, is a deposit of light-olive colored material of loose, fine, particulate consistency which is easily resuspended. This deposit is several centimeters thick in the deeper parts of the lake, and is composed of organic debris and the remains of animals, plants and bacteria that fell into the brine and were partially preserved. In 1976, thin, diffuse patches of purple were observed on the light-olive particulate deposit directly adjacent to the dark-olive mats near the lake's border. The purple color was absent in 1977 and thereafter (Bright et al., 1980b). The olive mats and purple coloration may be bacterial, possibly photosynthetic halophilic sulfur bacteria (e. g. Borowitzka, 1981).

Extensive white mats also cover the bottom and sides of the canyon wherever the brine stream touches the substratum. The white mat in Gollum's Canyon was dominated by Beggiatoa (a sulfide oxidizer) and other prokaryotes with some Oscillatoria filaments and pennate diatoms. These organisms were embedded in a mucilaginous matrix, probably of prokaryotic origin. Bacteria such as Beggiatoa need both hydrogen sulfide and oxygen, and therefore can only grow at a diffusion gradient (or in a mixing zone) where both are present (Jørgensen, 1977). The brine stream provides excellent conditions for sulfur bacteria of this type.

Diatoms were common and much more abundant in the mat than in other benthic 
samples collected away from the seep at similar depths on the bank. Though diatoms are not normally considered important members of a sulfuretum flora, other workers have found benthic diatoms capable of living in areas with relatively high sulfide concentrations (Admiraal \& Peletier, 1979; Round, 1979).

\section{Fauna}

Powell et al. (1983) divided the sandy-bottom biota into thiobios and oxybios. Thiobios, those organisms with an ecologic dependency on sulfide, consisted mostly of gnathostomulids, nematodes, oligochaetes, nereid polychaetes and some amphipods. They dominated the community in the brine seep canyon from Corner Pool to Cottonwick Rock. Oxybios, those organisms typical of normoxic sulfide-free habitats, were found below Cottonwick Rock, adjacent to the brine lake and throughout the general area. Oxybios comprised two groups; a downstream oxybios from below Cottonwick Rock to downstream of the canyon mouth, and the normal bank biota above Gollum's Lake in the brine lake basin and throughout the general area. Stations (e. g. 80-15, 80-16), where the normal bank biota were sampled far from the brine seep system to establish background taxonomic composition and abundance, will be referred to as control stations and the biota as control biota. We use the term control in the sense of Eskin \& Coull (1984) recognizing, as they describe, that these stations cannot be considered true controls in the strictest sense. Between Cottonwick Rock and the Anchor was a transition zone between the canyon thiobios and typical downstream, oxybiotic communities comprising a relatively sulfide-tolerant subset of the downstream oxybios. Gittings et al. (1984) described a similar community transition on the hard bottom. Cluster analysis supported this categorization on both the hard and sandy-bottom regardless of whether at the level of major taxon (Figs. 4, 5), family (e. g. polychaetes, Table 1, Fig. 6) or species (e. g. nematodes, Fig. 7). Only one hard-bottom station, Rl, clustered with any sandy-bottom stations. Consequently, substrate was the primary determinant of faunal distribution, except in the canyon brine stream where sulfide was dominant. Nevertheless, outside the canyon thiobios, and within the two major substrata (hard-bottom and sandy-bottom), the primary determinant of faunal distribution was distance from the brine source: that is, sulfide concentration and food supply determined faunal abundances and both were ultimately derived from Gollum's Lake and/or Gollum's Canyon. The implications of this hypothesis will be explored in more detail in the remainder of this paper.

\section{TROPHIC IMPACT OF THE BRINE SEEP SYSTEM}

\section{The halo model}

A 'halo' effect has been observed for both anthropogenic and natural discharge systems (Mackin, 1973; Davis \& Spies, 1980; Straughan, 1982) whereby microflora and microfauna dominate and are in high abundance near the discharge but macrofauna are poorly represented. Benthic meio- and macrofauna peak in abundance at different distances from the discharge, depending on the tolerance of the organisms to the stresses imposed by the discharge. In these areas, due to an increase in food produced by the 


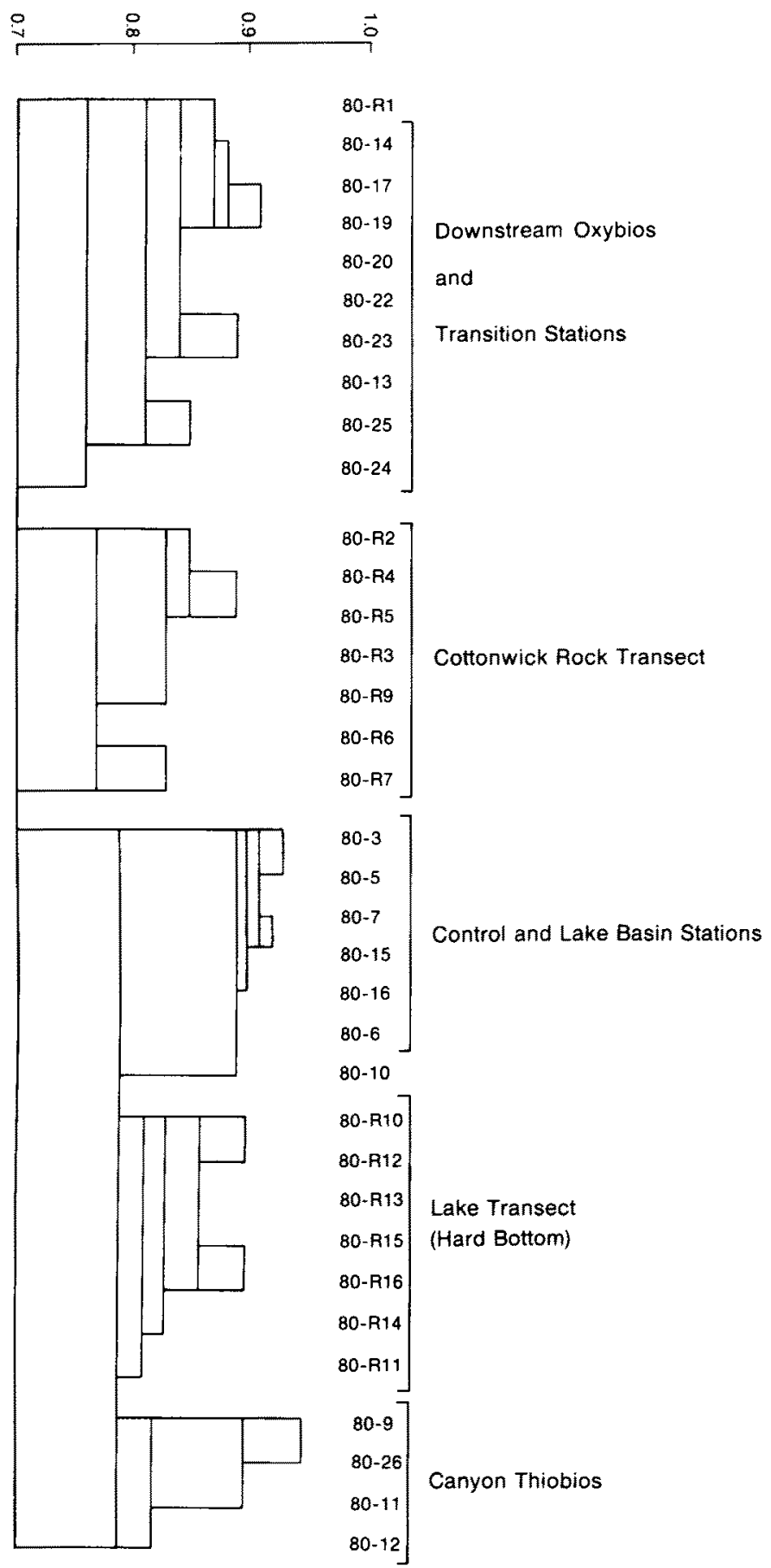

Fig. 4. Cluster analysis of the stations sampled in the EFG brine seep system based on the distribution and abundance of major taxa excluding meiofauna, hard and soft bottom 


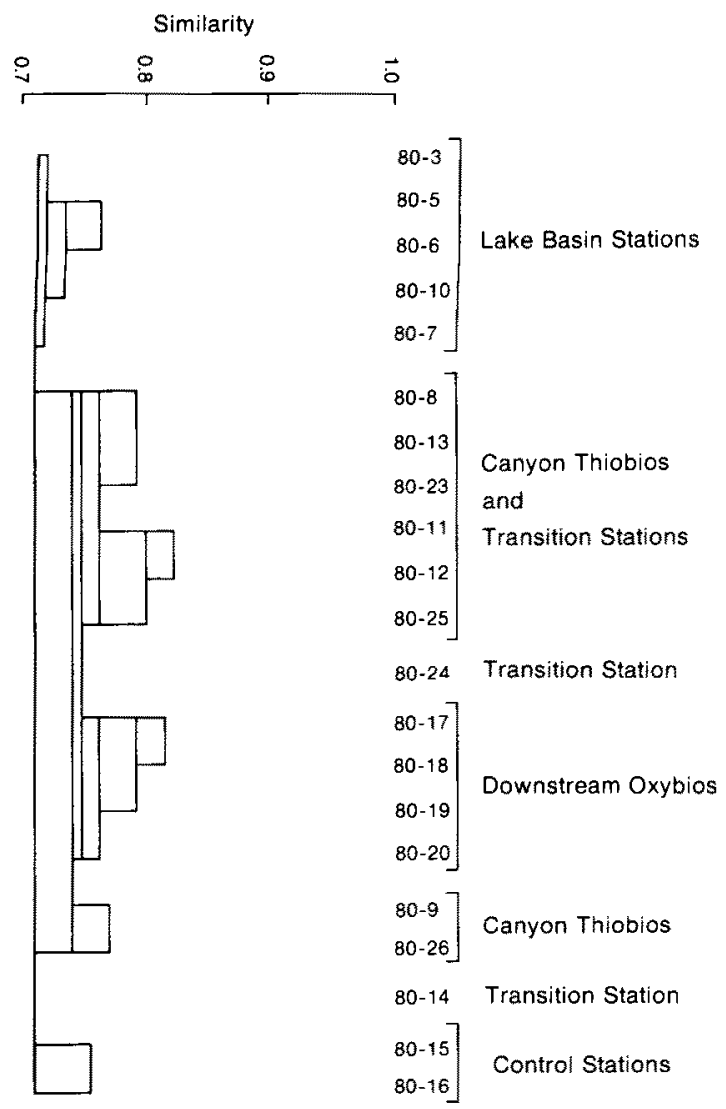

Fig. 5. Cluster analysis of the stations sampled in the EFG brine seep system based on the distribution and abundance of all taxa, meio- and macrofaunal, on the soft bottom

large microfloral populations often present, absolute abundances can be considerably above control levels even for those taxa also present in nearby, unstressed areas. In general, taxonomic composition tends to return to that of control areas before numerical abundance (Pearson, 1981).

The EFG brine seep system is no exception (Fig. 8). In this case, thiobios give way to sulfide-tolerant oxybios, which in turn give way to sulfide-intolerant oxybios with the distribution of taxa dependent primarily on sulfide concentration (Powell et al., 1983; Powell \& Bright, 1981; Gittings et al., 1984) (Figs. 9, 10, 11). Within the sulfide gradient, taxon abundances may be controlled primarily by food supply. Both Gittings et al. (1984) and Powell et al. (1983) reported increased abundances of oxybiotic organisms near the brine seep system (Fig. 10). They suggested that, whereas sulfide is both diluted by mixing processes and diminished by oxidation with oxygen, food supply is only diluted by mixing. The effect of an increased food supply, therefore, should extend beyond the influence of sulfide. Consequently, high abundances of oxybiotic taxa, especially those typical of control stations, might be explained if a mechanism for transfer of food from 


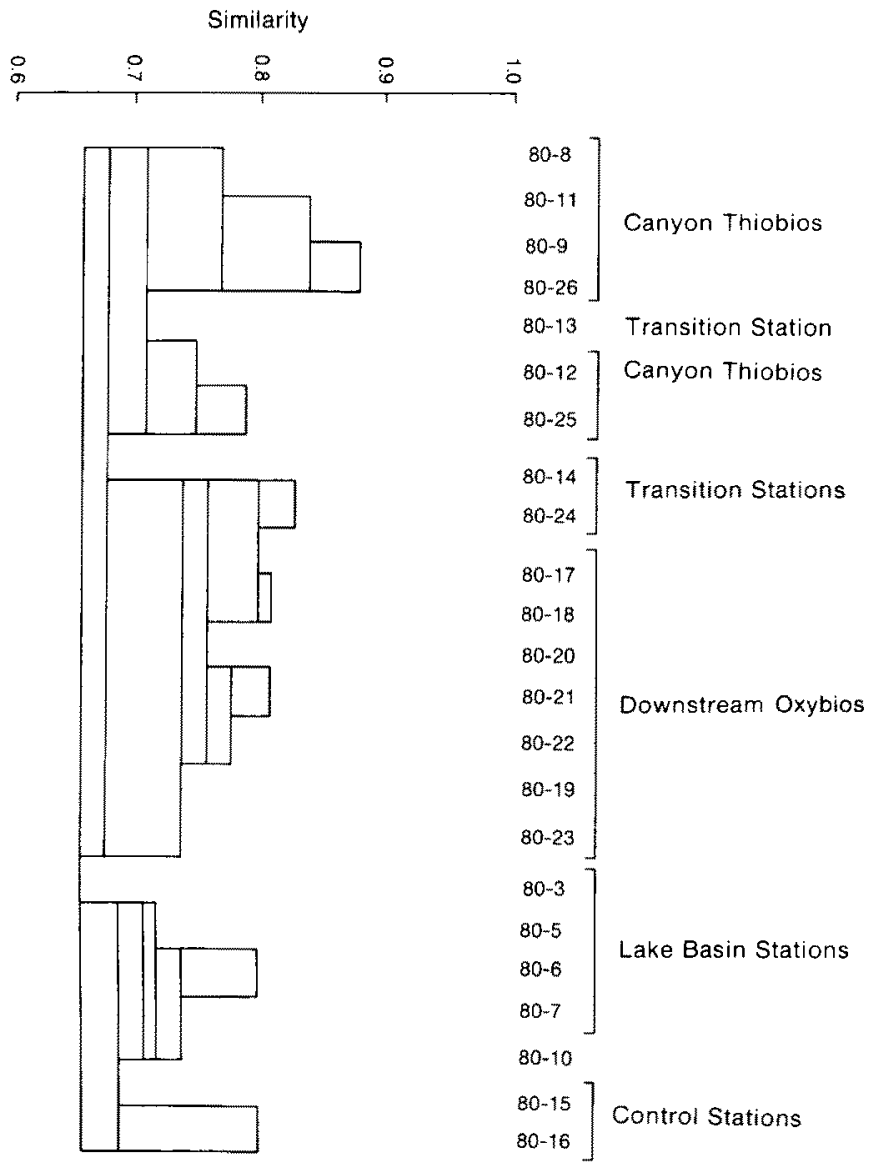

Fig. 6. Cluster analyses of the stations sampled in the EFG brine seep system based on the distribution and abundance of polychaete families

the sulfuretum to the oxybiotic communities downstream was present and if use of transported food by downstream biota could be demonstrated.

\section{The hydrodynamic-cropping model}

Three hydrodynamic factors are important in the brine seep system. (1) Gravitydriven flow occurs in Gollum's Lake and Canyon and advects material to the downstream sandy bottom. (2) Turbulent mixing created by the gravity-driven system advects material out of the canyon to the peripheral hard bottom. (3) Molecular diffusion moves brine across the lake-seawater interface whereupon advection moves it to the peripheral hard and sandy bottom of the Gollum's Lake basin. Autotrophy in the system depends on two energy sources: light and sulfide. The latter comes into the system with the brine and is delivered to the microflora by gravity-driven flow in the canyon and molecular diffusion across the lake-seawater interface. 


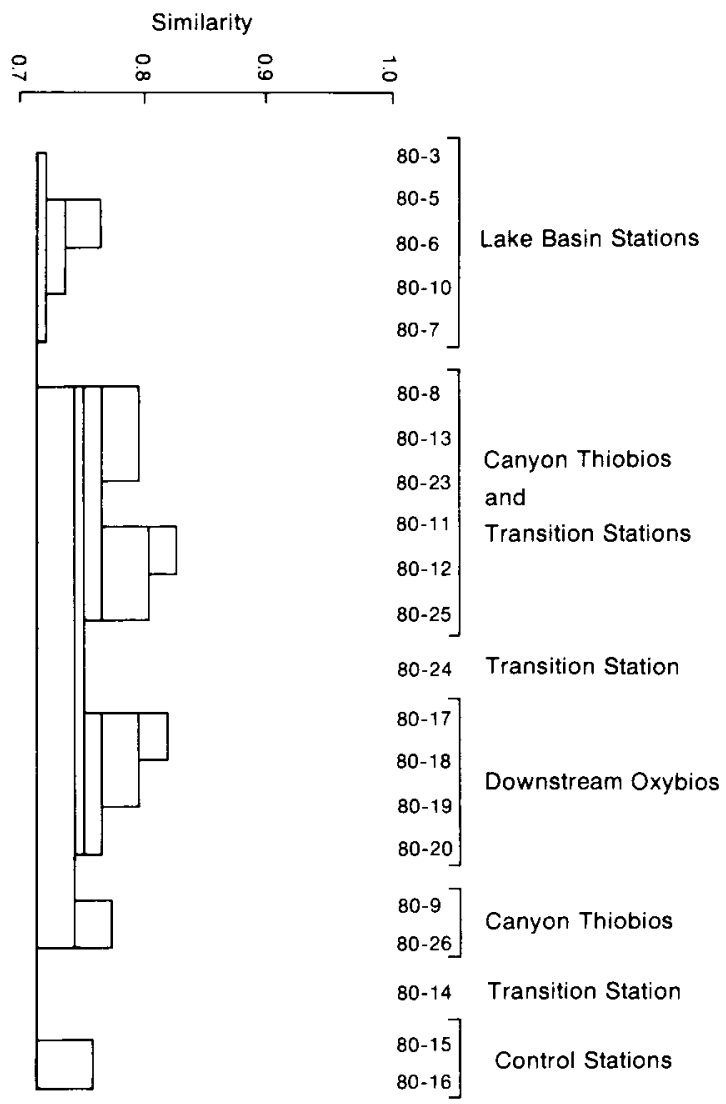

Fig. 7. Cluster analyses of the stations sampled in the EFG brine seep system based on the distribution and abundance of nematode species (pers. comm., P. Jensen, see Jensen, 1986 a, b, $c_{1}$ )

Food for the fauna is ultimately derived from two sources, autotrophy and detrital input. Oxybiotic primary production occurs on the peripheral hard bottom throughout the area. Significant thiobiotic production occurs on the floor of Gollum's Canyon and at the interface of Gollum's Lake. A third source may be the brine lake itself (Bright et al., 1980a). To the extent that Beggiatoa and other sulfide oxidizers are heterotrophic (Jørgensen, 1977), some thiobiotically-produced carbon in the canyon may be generated heterotrophically. Since, for the eukaryotic biota, the result is the same, this production has been included under the term "thiobiotic autotrophy" in Figure 12.

Heterotrophic eukaryotic consumption occurs in three ways. (1) Heterotrophs consume produced carbon at its source. This occurs in all oxybiotic habitats and by the thiobios in Gollum's Canyon. (2) Migrating subsystems (terminology of Copeland et al., 1974) comprising mobile organisms such as fish (Bright et al, 1980a) enter the canyon and downstream communities periodically to feed and then leave. (3) Gravity-driven circulation continually sweeps microbiota from the lake and canyon sulfureta downstream or advection mixes them up into the peripheral hard bottom for consumption 


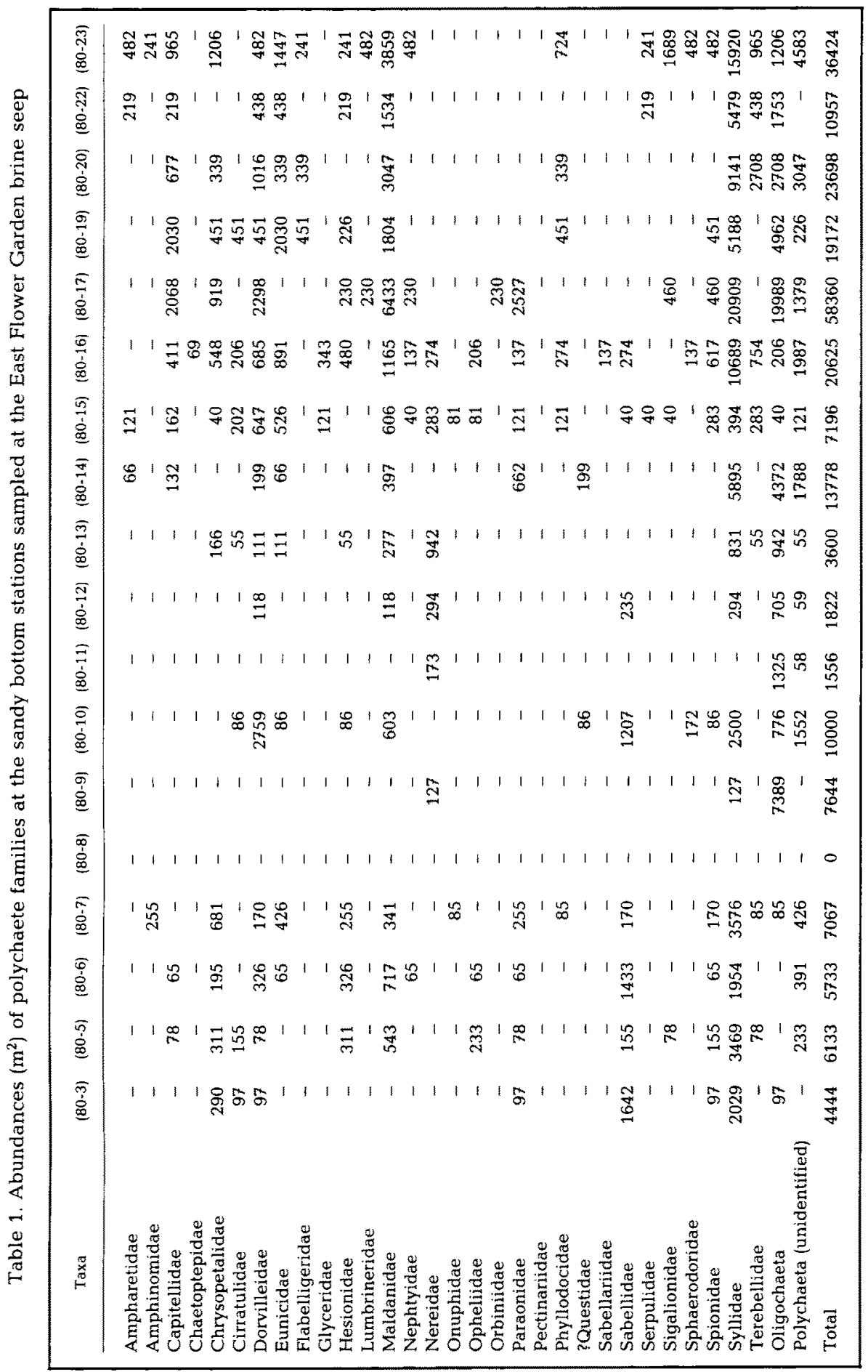




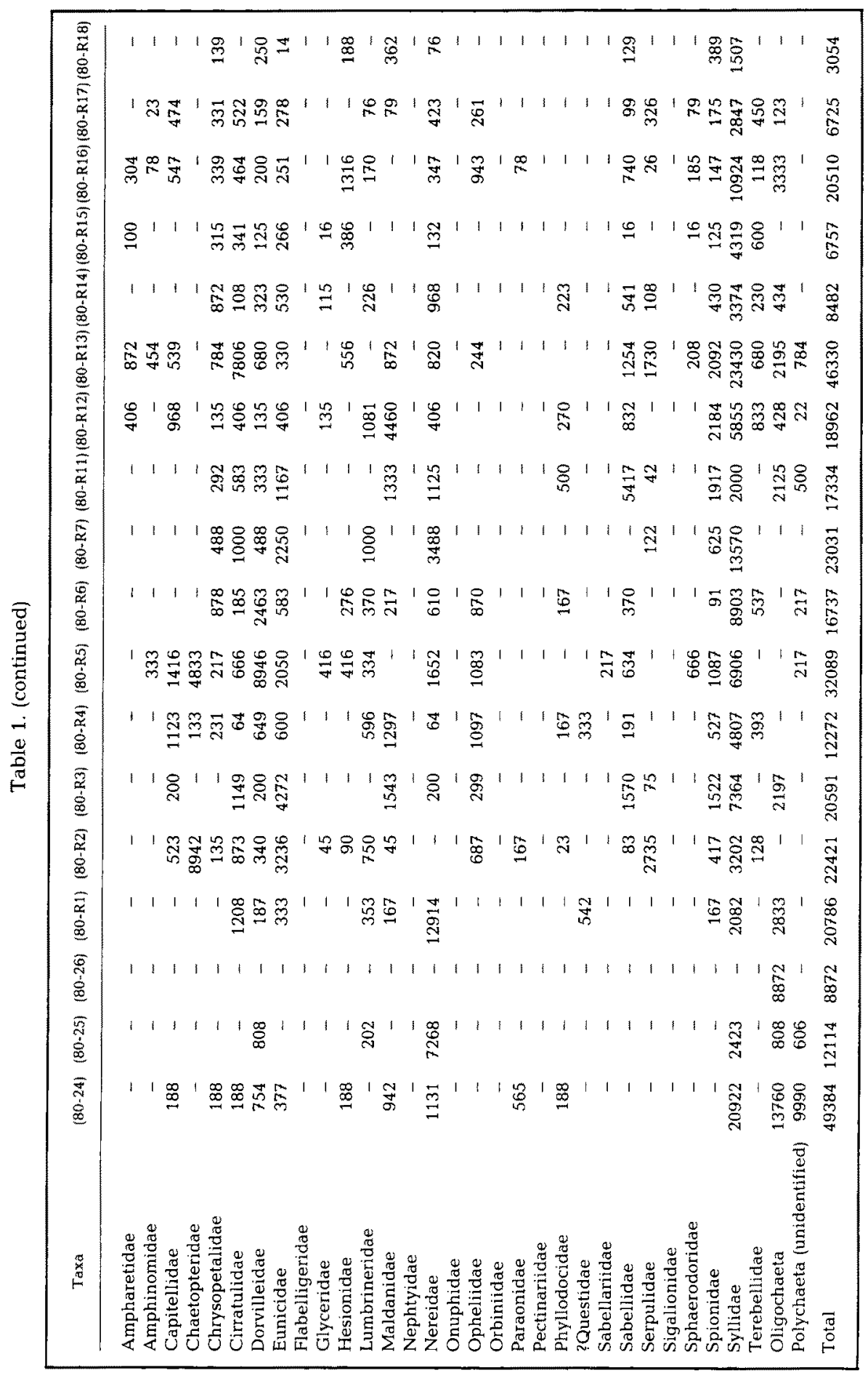




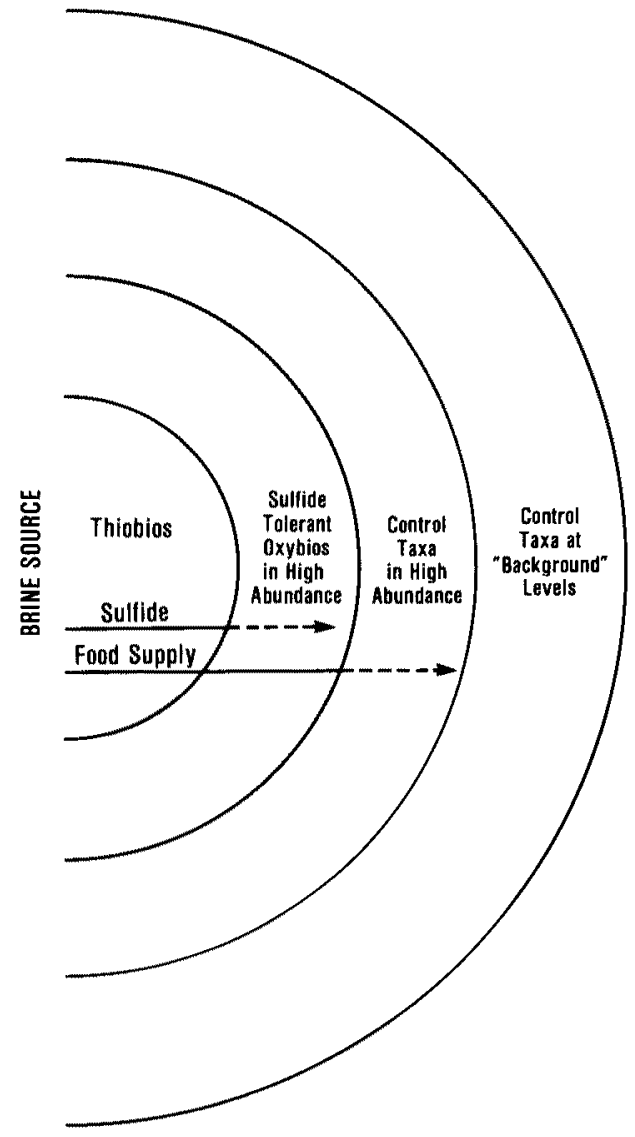

Fig. 8. The halo model

there by heterotrophs. We will term this last process hydrodynamic cropping. Probably, much of the heterotrophic communities contiguous to and downstream of the lake and canyon sulfureta derive part or all of their food from this process. For simplicity these communities will hereafter be termed downstream communities.

Hydrodynamic cropping requires that bacterial production must be high at the lake interface and in the canyon because the bacterial mats remain continuous in spite of it (Bright et al., 1980a; Powell et al., 1983). Flakes of elemental sulfur containing bacteria are continuously swept over the overflow from the Lake's interface, and portions of the Canyon's bacterial mat are continuously swept out of the canyon's mouth (Bright et al., $1980 a$, b). Hydrodynamic cropping would explain the observed increase in faunal abundances described in the halo model if it indeed supplied an important component of the food supply to the downstream communities.

\section{Changes in isotopic composition of the biota}

Stable carbon isotopes have been used to trace carbon flow in food chains (Haines \& Montague, 1979; McConnaughey \& McRoy, 1979; Rau et al., 1983). Brooks et al. (1979) 


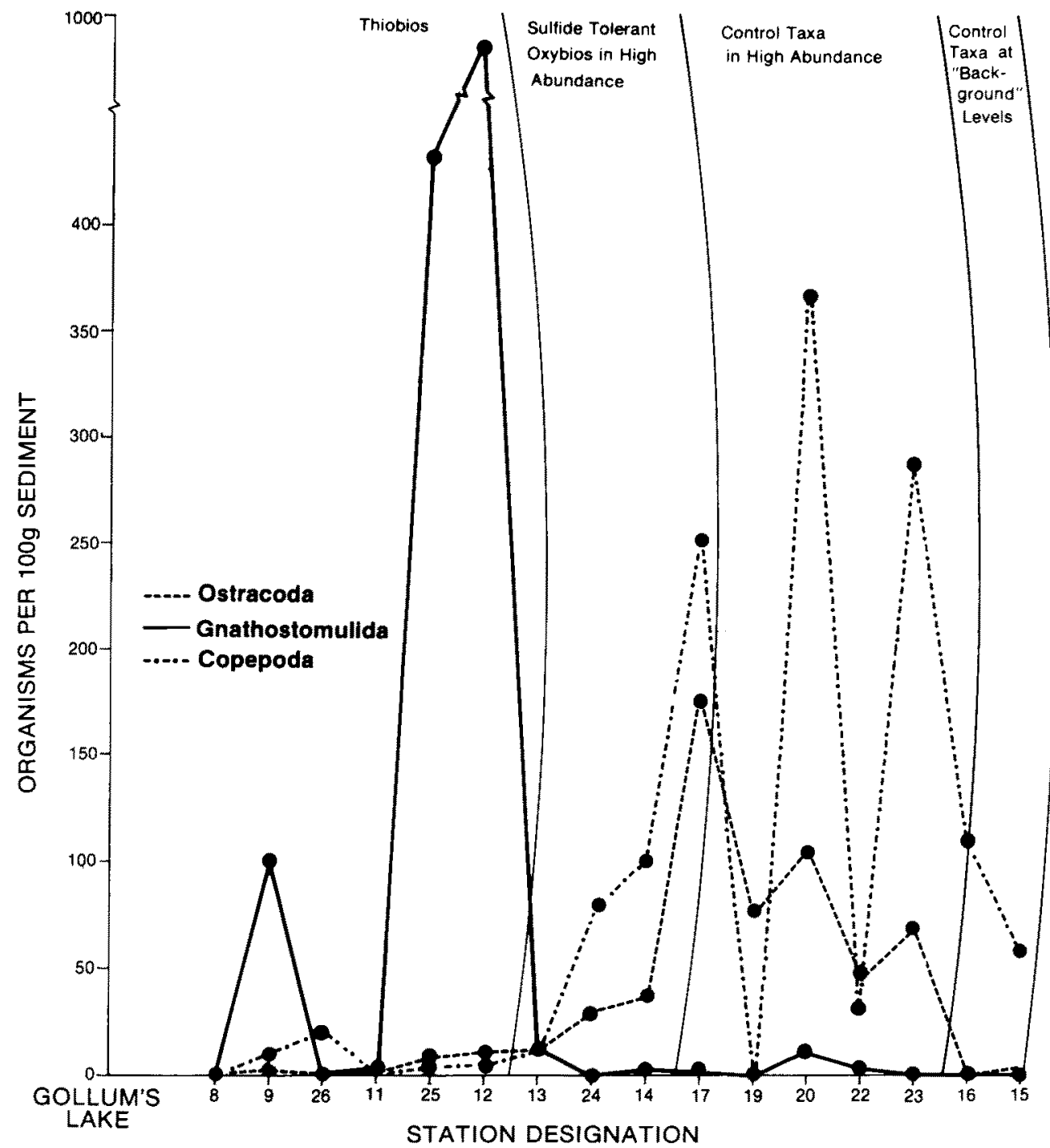

Fig. 9. Faunal distributions with respect to the halo model along a transect from Gollum's Lake, down Gollum's Canyon and out onto the adjacent sandy bottom below the canyon's mouth

reported that inorganic carbon derived from the brine seep had a $\delta^{13} \mathrm{C}$ value much more negative $(-23 \%)$ than normal seawater $(\simeq \mathrm{O} \%$ ) (and very similar to some crude oils typically associated with salt domes; Sofer, 1984). Inorganic carbon from the seep provides part of the carbon for thiobiotic production. In addition, many sulfur bacteria fractionate carbon (Wong et al., 1975) and have $\delta^{13} \mathrm{C}$ values different from other carbon producers (Fry \& Sherr, 1984). Consequently, carbon isotopes can be used to trace thiobiotically-produced carbon in this system.

The bacterial mat was very heterogeneous and was difficult to collect and prepare 


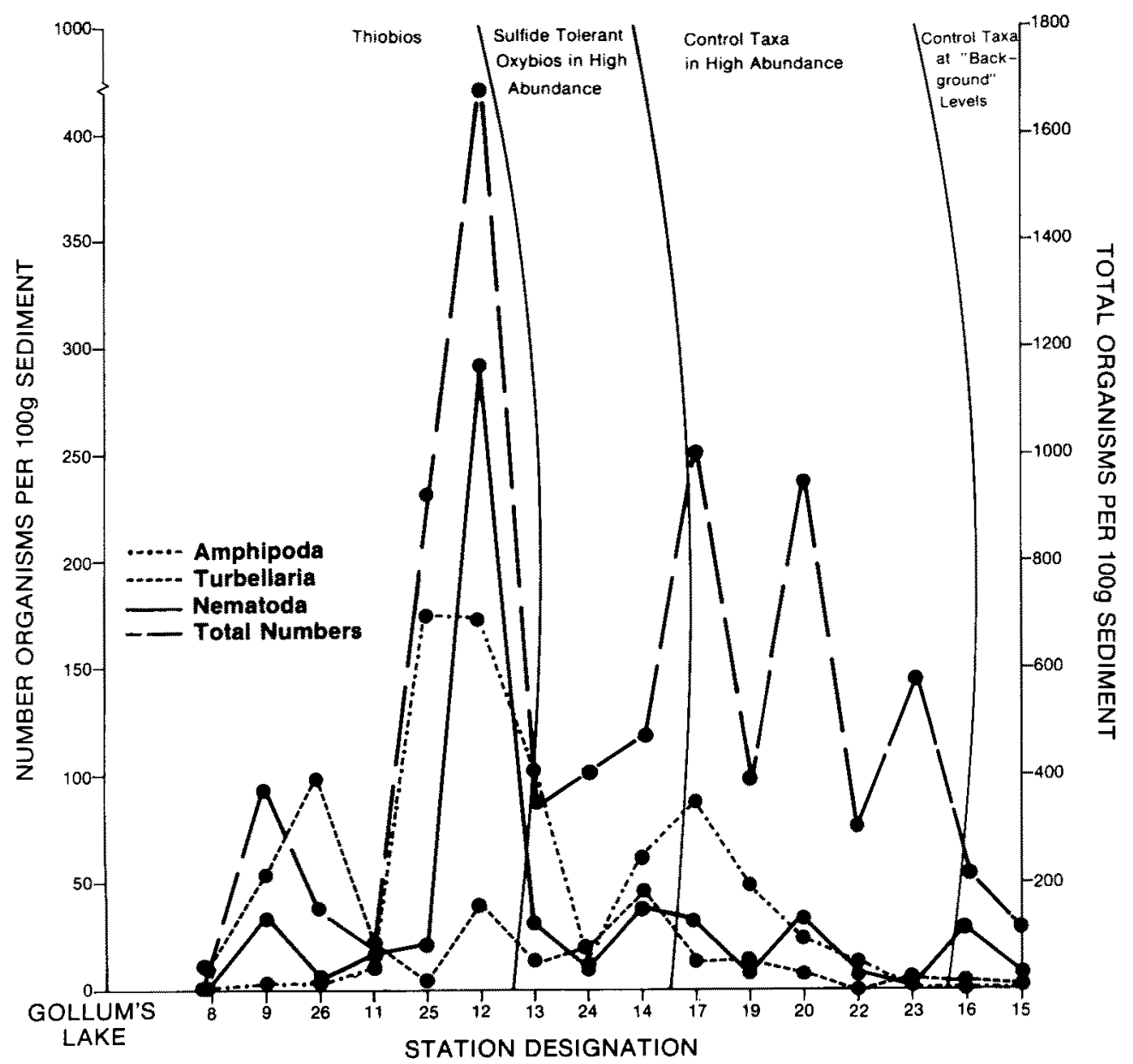

Fig. 10. Faunal distributions with respect to the halo model along a transect from Gollum's Lake, down Gollums's Canyon and out onto the adjacent sandy bottom below the canyon's mouth

for analysis free of detritus. Consequently, values varied considerably, but most were more negative $(-22$ to $-25.8 \%$ ) than local benthic algae (avg. $-19.3 \%$, $n=7$, range $-18.2 \%$ to $-20.3 \%$ ) and plankton from the Gulf of Mexico (Fry \& Parker, 1979 ; Thayer et al., 1983; Fry et al., 1984). The most negative values for local benthic algae, including one very unusual value of $-26.5 \%$, all came from Gollum's Canyon (Table 2). These may represent isotopic enrichment produced by gravity-driven circulation in the canyon reducing the size of the stagnant boundary layer around the alga through which ${ }^{12} \mathrm{C}$ and ${ }^{13} \mathrm{C}$ must diffuse; thereby enriching the plant in ${ }^{12} \mathrm{C}$ (Osmond et al., 1981; Jørgensen \& Revsbech, 1985; see Schidlowski et al. [1984] for the opposite effect). Consequently, both eukaryotic and prokaryotic primary producers in the canyon and lake sulfureta are characterized by light $\delta^{13} \mathrm{C}$ values.

Organic detritus from sediment in the canyon had $\delta^{13} \mathrm{C}$ values generally lower than other sediments in the area (cf. Parker et al., 1972; 1981). Stations above Cottonwick 


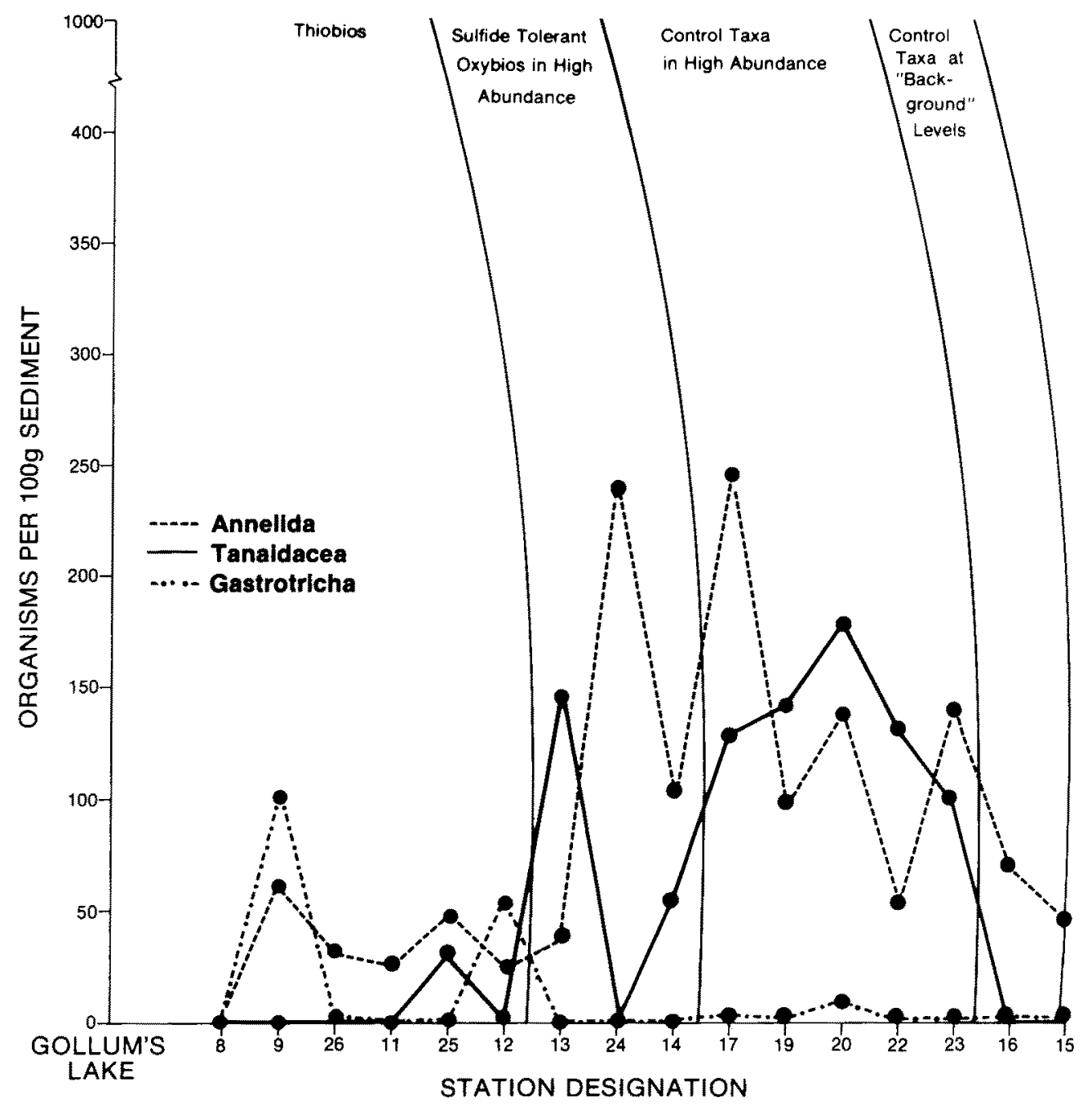

Fig. 11. Faunal distributions with respect to the halo model along a transect from Gollum's Lake, down Gollum's Canyon and out onto the adjacent sandy bottom below the canyon's mouth

Rock averaged $-21.2 \%$. Values became less negative with distance downstream of the canyon mouth and were least negative at the control station which had a value fairly typical of other shallow-water coarse carbonate sands (Black \& Bender, 1976; Fry \& Parker, 1979). This trend is significant (Daniel's test for trend, $\mathrm{P}<.01$ ). Differential heterotrophic utilization of portions of the detrital pool at the various stations might produce such a trend, however, more likely the mixing of two sources of different isotopic composition is responsible. If the latter, then about $40-60 \%$ of the detritus below the canyon's mouth is derived from the upstream sulfureta.

Most $\delta^{13} \mathrm{C}$ values for animals were more negative than would be expected if the carbon source were either local benthic algae or plankton. Sponges, for example, from 


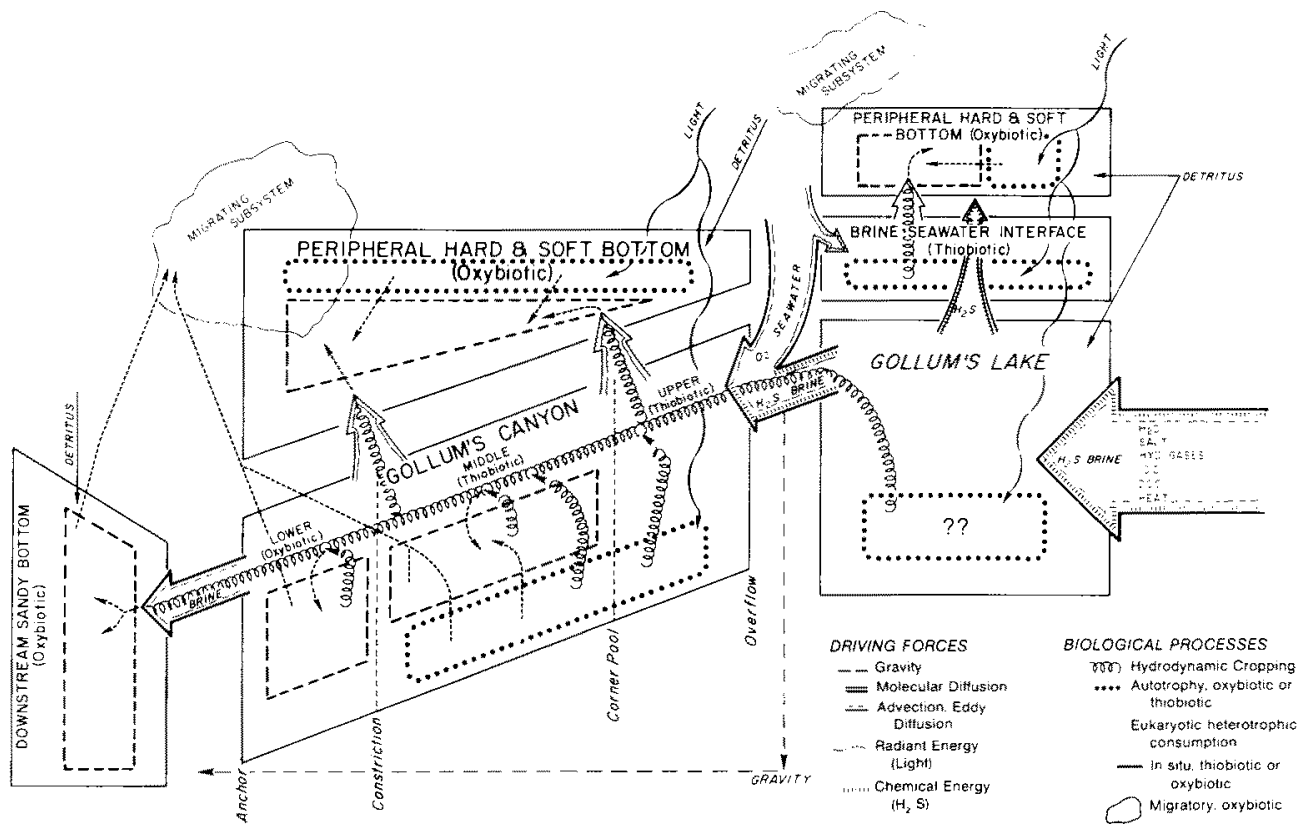

Fig. 12. The hydrodynamic-cropping model. Autotrophy includes sulfide-oxidizing heterotrophy as well as true autotrophy. Other bacterial heterotrophy occurs in all systems and can be expected to provide a food source for metazoans but is not included in the diagram. Box and arrow size do not imply any quantitative relationships

control stations had values typical for animals whose food source, ultimately, was marine algae $(-20$ to $-20.5 \%, \mathrm{n}=3)$, whereas sponges from stations near Gollum's Lake and Canyon had values ranging from -25.4 to $-27.6 \%(n=3)$. These low values suggest that carbon from the brine seep sulfureta was the ultimate food source. Most of the $\delta^{13} \mathrm{C}$ values for polychaetes (avg. $-23.0 \%, \mathrm{n}=5$ ) and crustaceans (avg. $-24.5 \%, \mathrm{n}=3$ ) from Gollum's Canyon were more negative than local benthic algae, suggesting that carbon from the brine seep sulfureta was the ultimate food source for them as well. Polychaetes from below the canyon's mouth had higher values (avg. $-18.8 \%, n=2$ ) than crustaceans (avg, $-25.8 \%, n=3$ ) suggesting that these crustaceans are more dependent on carbon from the sulfureta than are the polychaetes. In fact, the carbon isotopic composition of the polychaetes taken from stations below the canyon mouth was not distinct from detritus in the same area whereas crustaceans had much lower values. Consequently, the evidence indicates that a considerable portion of the carbon used by macrofauna in the brine seep area is derived from the sulfureta and that hydrodynamic cropping must play an important role in the transport of this carbon to downstream communities.

\section{Effect of variation in food supply}

How the quantity and quality of food available structure benthic communities has received considerable theoretical (e. g. Levinton, 1972; Wangersky \& Wangersky, 1981; Levine, 1980; Hoffman, 1978) and experimental (e. g. Bianchi \& Levinton, 1981; Young \& 
Table 2. Carbon isotopic composition $\left(\% \delta^{13} \mathrm{C}\right)$ of the biota of the East Flower Garden brine seep system

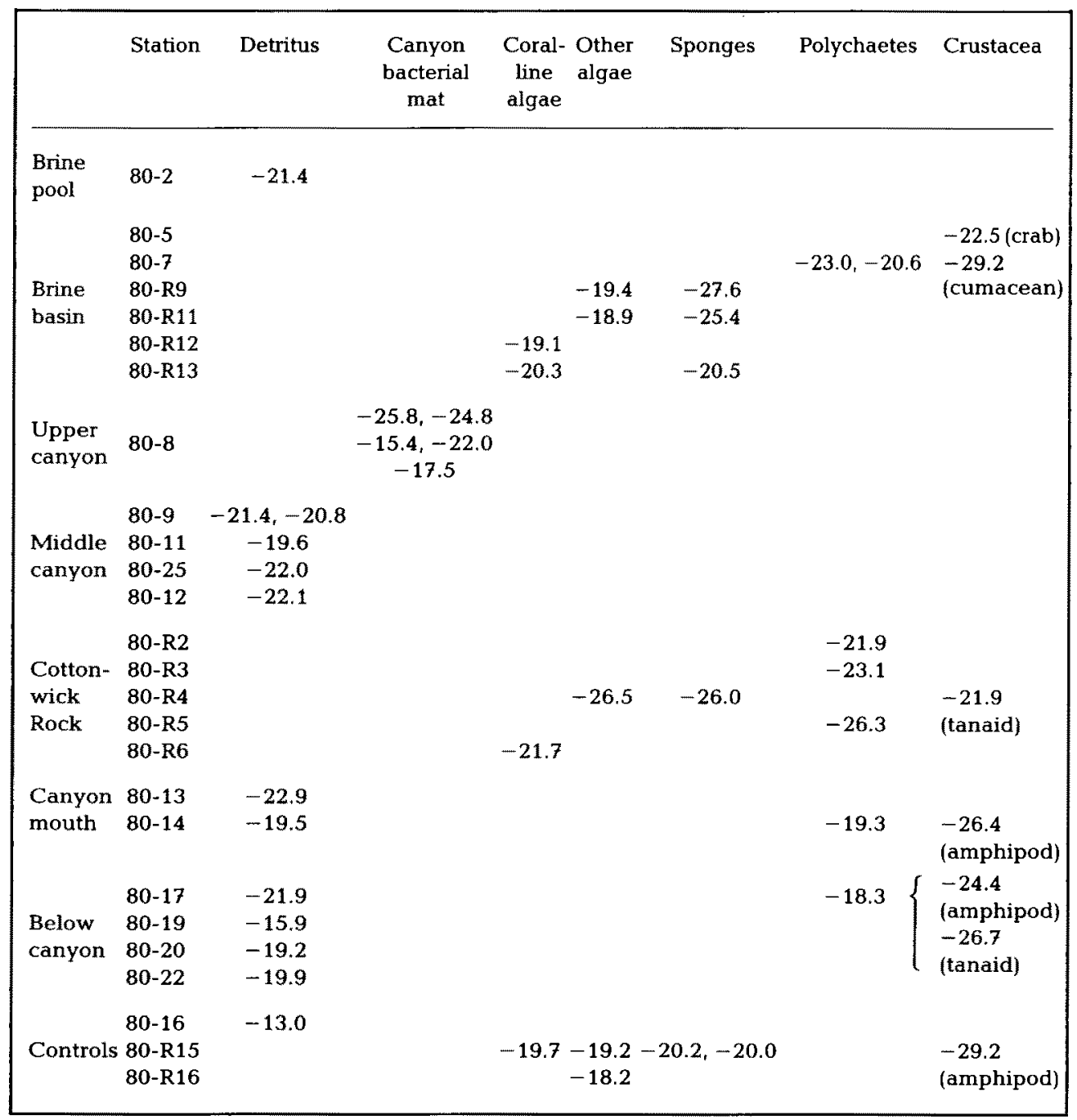

Young, 1978; Montagna et al., 1983; Tenore, 1983) attention. Field studies comparing food supply generally are difficult because experimental manipulation occurs on time scales too short for establishment of a new equilibrium condition, the food added is rarely natural in the purest sense of the word, and control sites are difficult to identify (Peterson, 1980). The brine seep provides a good natural experiment to investigate the effect of food supply. Certainly an equilibrium condition exists and the food supply is produced naturally. The problem of control sites is mitigated by the great similarity between the physical parameters of downstream and control communities. Most parameters such as sediment texture, light and temperature are the same. Sulfide is certainly 
below levels producing significant effects. Only food supply and the flow regime carrying it are very different. Moreover, the food being exported is used.

In the following discussion, we do not wish to imply that downstream communities are not food-limited, although this may be true. Rather, we will simply discuss the impact of an increased food supply on a previously food-limited community. We make the comparisons based numerical abundance, although biomass would be better; however, the general trends should remain the same because the observed increases in numbers are produced primarily by macrofauna and, thus, should indicate substantial increases in biomass as well. Finally, we compare meiofauna to macrofauna based not on size, but taxonomic position because most of the meiofauna are relatively large. Many gnathostomulids, for example, were retained on a $500 \mu \mathrm{m}$ screen. Consequently, we compare permanent meiofauna with the combined values for macrofauna and temporary meiofauna, using taxonomy as the distinguishing characteristic.

An increase in food supply has produced two effects, a quantitative increase in total numbers and a relative change in the abundances of the various taxa. Absolute abundances of meio- and macrofauna are relatively low at both control and downstream stations compared to most continental shelf sites (see references in Table 3), rarely

Table 3. Relative importance of permanent meiofauna in subtidal benthic communities exclusive of the deep sea. Range of values in brackets

\begin{tabular}{|lcc|}
\hline \multicolumn{1}{|c|}{ Source } & $\begin{array}{c}\text { Percent permanent meiofauna (as defined in Table 4) } \\
\text { Average }\end{array}$ & Range \\
\hline Renaud-Mornant et al. (1971) & $56.9(\mathrm{n}=5)$ & {$[58.0-80.8]$} \\
Ankar \& Elmgren (1976) & 99.0 & \\
Mare (1942) & 85.9 & {$[75.0-91.9]$} \\
Guille \& Soyer (1968) & $86.0(\mathrm{n}=6)$ & {$[86.1-98.6]$} \\
Thomassin et al. (1976) & $94.7(\mathrm{n}=10)$ & {$[89.3-98.4]$} \\
Wigley \& McIntyre (1964) & $96.1(\mathrm{n}=10)$ & {$[73.9-90.7]$} \\
McIntyre (1961) & $82.3(\mathrm{n}=2)$ & {$[53.6-98.9]$} \\
Sanders (1960), Wieser (1960) & 98.9 & {$[48.3-91.8]$} \\
Thomassin et al. (1982) & $66.7(\mathrm{n}=5)$ & \\
Ansari (1984) & $67.8(\mathrm{n}=4)$ & \\
East Flower Garden & & \\
Control stations & 65 & \\
Thiobios & 75 & \\
Downstream oxybios & 44 & \\
\hline
\end{tabular}

exceeding 100,000 animals per $\mathrm{m}^{2}$, whereas typical literature values for continental shelves in general frequently exceed $200,000-300,000$ per $\mathrm{m}^{2}$. Control stations, however, were decidedly depauperate by any comparison, 20,000 to 65,000 per $\mathrm{m}^{2}$, whereas 3 of 5 stations downstream of the canyon mouth exceeded 150,000 organisms per $\mathrm{m}^{2}$, more than double control station values. A similar phenomenon occurred on the hard bottom (Gittings et al., 1984).

Powell et al. (1983) and Gittings et al. (1984) attributed the increase in total numbers at downstream stations to an increase in food supply. Low abundances at control stations 
suggest a food-limited situation. An alternative hypothesis would invoke differential predation pressure at control and downstream stations (e.g. Virnstein 1977, 1979; Bell \& Coull, 1978); competition for space is rarely observed (e. g. Peterson 1977, 1982) and certainly cannot be a limiting factor here (Gittings et al., 1984). Our observations suggest that, if anything, predators such as fish are in higher abundance in and around the brine seep system than elsewhere. Nevertheless, most taxa are substantially more abundant at downstream stations than control stations. In addition, substantially higher macrofaunal numbers do not prevent a concomitant substantial increase in meiofaunal numbers even though predation by macrofauna on meiofauna probably is significant (e. g. Bell \& Coull, 1978; Reise, 1979). Food limitation at the control stations offers the better explanation (see also Yingst \& Rhoads, 1985).

Relative changes in abundance among the various taxa between control and downstream stations support this view. We divided the sandy-bottom stations into 3 groups, based on the cluster analyses, and compared the average composition of the three: stations dominated by thiobios $(80-12,80-25)$, control stations $(80-15,80-16)$; downstream stations nearest the canyon mouth but beyond the transition zone just below Cottonwick Rock (80-17, 80-19, 80-20). Thiobios were dominated by the lower Bilaterian (Table 4) groups of meiofauna because, overall, these groups have a greater tolerance for sulfide (Powell et al., 1983). Obviously, the lower Bilaterian groups exploit the food source in the canyon. One might expect that these groups should be important components at the stations below the canyon mouth. This is not the case. In fact, they account for only $5 \%$ of the total biota, less than half as much as at the control stations and their numbers increase by only 1.6 times between control and downstream stations (Table 5). Moreover, the abundance of nematodes, the second most numerous group of

Table 4. Percent contributions of macrofaunal taxa and meiofaunal taxa (as defined in the text) in the East Flower Garden brine seep area. Higher Bilaterian meiofauna include copepods, ostracods and mites. Lower Bilaterian groups include turbellarians, nemerteans, gnathostomulids, nematodes and gastrotrichs. Macrofaunal groups include annelids, molluscs, cumaceans, tanaidaceans, amphipods, isopods, etc

\begin{tabular}{|lcrr|}
\hline Faunal assemblages & Macrofaunal taxa (\%) & \multicolumn{2}{c|}{ Meiofaunal taxa (\%) } \\
& & Lower Bilateria & Higher Bilateria \\
\hline Control & 35 & 13 & 52 \\
Thiobios & 25 & 74 & 39 \\
Downstream oxybios & 56 & 5 & 39 \\
\hline
\end{tabular}

Table 5. Relative change in abundance between thiobios and downstream oxybios vs. control stations. $\Delta$ increase over control levels; $\nabla$ decrease from control levels

\begin{tabular}{|c|c|c|c|}
\hline \multirow[t]{2}{*}{ Faunal assemblages } & \multirow[t]{2}{*}{ Macrofaunal taxa } & \multicolumn{2}{|c|}{ Meiofaunal taxa } \\
\hline & & Lower Bilateria & Higher Bilateria \\
\hline Thiobios & $\Delta 2.9 \times$ & $\Delta 22.7 \times$ & $\nabla 11.3 \times$ \\
\hline Downstream oxybios & $\Delta 6.8 \times$ & $\Delta 1.6 \times$ & $\Delta 3.1 \times$ \\
\hline
\end{tabular}


the meiofauna at control stations, does not change at all, although numbers do increase substantially in the thiobios. By comparison, copepods and ostracods increase dramatically between control and downstream stations; the higher Bilaterian groups averaging 3.1 times more abundant downstream of the canyon mouth. This suggests that meiofauna may be divided into two relatively independent groups in this area based on their response to increased food supply and the presence or absence of sulfide and that this division follows phylogenetic lines.

The nematode/copepod ratio was above 1 only in the thiobios of the canyon. Raffaelli \& Mason (1981) and Raffaelli (1981) proposed the use of the nematode/copepod ratio as a pollution monitoring tool, although Pequegnat \& Sikora (1977) had employed it earlier. Coull et al. (1981) and Lambshead (1984) have disputed its usefulness. Nematodes exploit sulfide systems considerably better than copepods. Any factors, including various pollutants, which tend to increase sulfide concentration will increase the relative importance of nematodes. We suggest that much of the significance of the nematode/copepod ratio can be reinterpreted based on the relative importance of sulfide-tolerant organisms in the community. We point out, however, as did Gittings et al. (1984), that this does not necessarily mean that these sulfide-tolerant organisms are thiobiotic.

Copepods, and meiofauna in general, dominate the control stations, making up $65 \%$ of the biota. This is a relatively low percentage compared to literature values (Table 3). In most terrigenous sediments, permanent meiofauna account for over $90 \%$ of all metazoans. Only carbonate sands such as those at the Flower Gardens yield percentages below about $70 \%$. The EFG control stations are fairly typical. Apparently, carbonate sands are exploited better by taxa comprising mostly macrofauna.

By any measure, however, the proportion of permanent meiofauna in the downstream stations is extraordinarily low. Macrofaunal taxa predominate. Even if the oligochaetes and archiannelids were considered meiofaunal (all annelids were lumped for the calculations in Tables 4 and 5), the remaining macrofauna would account for over half of all the metazoan biota.

A comparison of the control stations and the downstream stations shows that not all oxybiotic taxa increase in numbers equally (Table 6). Macrofaunal numbers increase about 7 times, whereas meiofaunal numbers increase only 3 times compared to control stations. Consequently, the change in dominance between control and downstream stations is produced by a relatively much larger increase in macrofauna in spite of a substantial increase in meiofauna. Crustacean taxa (tanaidaceans, isopods, amphipods) are the primary contributors. Each contributed less than $1 \%$ of the biota at control stations, but numbers downstream of the canyon mouth are $\simeq 150$ times control levels. In contrast, annelid numbers only double. Interestingly, this relative difference corresponds with the carbon isotopic composition of the biota. Crustaceans utilized the food produced in the brine seep sulfureta to a much greater extent than did the annelids (Table 2).

The trophic interaction between meiofauna and macrofauna has been controversial for over a decade. Gerlach (1971) and Witte \& Zijlstra (1984) summarized evidence suggesting that macrofauna and meiofauna were more or less independent components of the community. Others, such as Bell \& Coull (1978); Reise (1977); Kuipers et al. (1981) and Gerlach (1978) stressed the importance of a trophic link; viz. macrofauna exert a 
Table 6. Relative change in abundance of numerically important taxa $\left(>500 / \mathrm{m}^{2}\right)$ between control stations and stations downstream of the canyon mouth. $\Delta$ increase over control levels

\begin{tabular}{|c|c|}
\hline Taxa & Change in numerical abundance \\
\hline Annelida & $\Delta \quad 2.4 \times$ \\
\hline Copepoda & $\triangle \quad 2.0 \times$ \\
\hline Ostracoda & A $106.6 \times$ \\
\hline Tanaidacea & $\Delta 145.1 \times$ \\
\hline Amphipoda & $4190.5 \times$ \\
\hline Isopoda & $4145.5 \times$ \\
\hline
\end{tabular}

measurable predative impact on meiofauna and at times, although more rarely, meiofauna may be important dietary components for macrofauna. The change in abundance between control and downstream stations, hard or sandy-bottom, indicates that typical continental shelf communities in the northwest Gulf of Mexico at these depths exist in a food-limited condition. Consequently, an important alternative question is, in food-limited situations, can meiofauna compete with macrofauna for food (McIntyre, 1969; Elmgren, 1976; Heip et al., 1982)?

Two explanations exist for the observed predominance of meiofauna at control sites and macrofauna at downstream sites. Either meiofauna monopolize the food supply when food supply is low such as at the control sites or the food delivered to downstream sites by hydrodynamic cropping is packaged such that it is more readily available to macrofauna. The correct choice between the two alternatives cannot be made using the present data, however a few observations are possible. The physical regime provides the opportunity for a dramatic increase in suspension feeders, which one might expect to be mostly macrofaunal, to exploit a suspended food source. The carbon isotope values suggest that the water-borne food is utilized by the crustaceans before it becomes part of the overall detrital pool used by the annelids for example. Much of the increased abundance of macrofauna at these stations involves these crustaceans. However, although the macrofaunal tanaids may be primarily suspension feeders, the amphipods and isopods are not and the suspension feeding Polychaeta increase hardly at all (Table 1). Moreover, a dramatic increase in ostracods at downstream stations suggests that meiofaunal-sized organisms can exploit the new food source just as well. Consequently, the dramatic increase in abundance of macrofauna at downstream stations probably cannot be totally explained by a shift in food location and availability.

The data agree best with the views of Heip et al. (1982) and Elmgren (1976) that, when food availability is low, more of the energy flow will be through the meiofaunal compartment of the community. At the EFG, where meiofaunal taxa, on the average, are large, some nearly of macrofaunal size, such a phenomenon may be even more pronounced (see Warwick, 1984). Consequently, the faunal distributions on the sandy bottom at the EFG brine seep are determined by sulfide and food supply. Whenever sulfide is present, the lower Bilaterian groups of meiofauna dominate. In the absence of sulfide, the relative proportions of macrofauna and meiofauna are determined by food supply. When food supply is low, as it probably is on most of the EFG at these depths, meiofauna, particularly the copepods, utilize a relatively large share of the available food. As food supply increases, the macrofauna dominate the community. 
Acknowledgements. Dr. R. Farris and S. Jameson provided invaluable help on the cruise. Our special thanks to them, the scientists and staff of the Harbor Branch Foundation, and the crew of the R. V. 'Johnson' and research submersible 'Johnson Sea-Link' whose extra effort before and during the cruise made it a success. J. Kendall and S. Connor helped with mobilization for the cruise. We thank J. Parrack for helpful suggestions that improved the manuscript and A. Koch for the typing. The work was supported by grants from NOAA Office of Coastal Zone Management NA80AA-HCZ118 and the National Science Foundation OCE-8019458 to EP and TB, OCE-8219792 to EP and several grants from the Minerals Management Service to TB. Any opinions, findings and conclusions or recommendations expressed in this publication are those of the authors and do not necessarily reflect the views of NOAA-OCZM, NSF or MMS.

\section{LITERATURE CITED}

Admiraal, A. \& Peletier, H., 1979. Sulphide tolerance of benthic diatoms in relation to their distribution in an estuary. - Br. phycol. J. 14, 185-196.

Ankar, S. \& Elmgren, R., 1976. The benthic macro- and meiofauna of the Askö-Landsort area (northern Baltic proper) a stratified random sampling survey. - Contr. Askö Lab. 11, 1-115.

Ansari, Z. A., 1984. Benthic macro- and meiofauna of seagrass (Thalassia hemprichil) bed at Minicoy, Lakshadweep. - Ind. J. mar. Sci. 13, 126-127.

Ballard, R. D. \& Grassle, J. F., 1979. Return to oases of the deep. - Natn. geogr. Mag. 156, 689-705.

Bell, S. S. \& Coull, B. C., 1978. Field evidence that shrimp predation regulates meiofauna. Oecologia $35,141-148$.

Bianchi, T. S. \& Levinton, J. S., 1981. Nutrition and food limitation of deposit-feeders. II. Differential effects of Hydrobia totteni and Ilyanassa obsoleta on the microbial community. - J. mar. Res. 39, $547-556$.

Black, C. C., Jr. \& Bender, M. M., 1976. $\delta^{13} \mathrm{C}$ values in marine organisms from the Great Barrier Reef.-Aust. J. Pl. Physiol. 3, 25-32.

Borowitzka, L. J. 1981. The microflora adaptations to life in extremely saline lakes. - Hydrobiologia $81,33-46$.

Bright, T. J., Powell, E. N. \& Rezak, R., 1980a. Environmental effects of a natural brine seep at the East Flower Garden Bank, northwestern Gulf of Mexico. In: Marine environmental pollution hydrocarbons. Ed. by R. Geyer. Elsevier, New York, 1, 291-316.

Bright, T. J., LaRock, P., Lauer, R. \& Brooks, J., 1980b. A brine seep at the East Flower Garden Bank, northwestern Gulf of Mexico. - Int. Revue ges. Hydrobiol. 65, 535-549.

Brooks, D. A., 1983. The wake of Hurricane Allen in the western Gulf of Mexico. - J. phys. Oceanogr, 13, 117-129.

Brooks, J. M., Bright, T. J., Bernard, B. B. \& Schwab, C. R., 1979. Chemical aspects of a brine pool at the East Flower Garden Bank, northwestern Gulf of Mexico. - Limnol. Oceanogr. 24, 735-745.

Cline, J. D. \& Richards, F. A., 1969. Oxygenation of hydrogen sulfide in seawater at constant salinity, temperature, and $\mathrm{pH}$. - Environ. Sci. Technol. 3, 838-843.

Comita, P. B., Gagosian, R. B. \& Williams, P. M., 1984. Suspended particulate organic material from hydrothermal vent waters at $21^{\circ} \mathrm{N}$. - Nature, Lond. 307, 450-453.

Copeland, B. J, Odum, H. T. \& Moseley, F. N., 1974. Migrating subsystems. In: Coastal ecological systems of the United States. Ed. by H. Odum, B. Copeland \& E. McMahon. Conservation Fdn, Washington, D. C., 3, 422-453.

Coull, B. C., Hicks, G. R. F. \& Wells, J. B. J, 1981. Nematode/copepod ratios for monitoring pollution: a rebuttal. - Mar. Pollut. Bull. 12, 378-381.

Dauer, D. M., Ewing, R. M., Tourtellotte, G. H., Harlan, W. T., Sourbeer, J. W. \& Barker, H. R., 1982. Predation, resource limitation and the structure of benthic infaunal communities of the lower Chesapeake Bay. - Int. Revue ges. Hydrobiol. 67, 477-489.

Davis, P. H. \& Spies, R. B., 1980. Infaunal benthos of a natural petroleum seep: study of community structure. - Mar. Biol. 59, 31-41.

Elmgren, R., 1976. Baltic benthos communities and the role of the meiofauna, - Contr. Askö Lab. 14, $1-31$. 
Enright, J. T., Newman, W. A., Hessler, R. R. \& McGowan, J. A., 1981. Deep ocean hydrothermal vent communities. - Nature, Lond. 289, 219-221.

Eskin, R. A. \& Coull, B. C., 1984. A prior determination of valid control sites: an example using marine meiobenthic nematodes. - Mar, environ. Res. 12, 161-172.

Fry, B. \& Parker, P. L., 1979. Animal diet in Texas seagrass meadows: $\delta^{13} \mathrm{C}$ evidence for the importance of benthic plants. - Estuar. coast. mar. Sci. 8, 499-509.

Fry, B. \& Sherr, E. B., 1984. $\delta^{13} \mathrm{C}$ measurements as indicators of carbon flow in marine and freshwater ecosystems. - Contr. mar. Sci. 27, 13-48.

Fry, B., Anderson, R. K., Entzeroth, L., Bird, J. C. \& Parker, P. L., $1984 .{ }^{13} \mathrm{C}$ enrichment and oceanic food web structure in the northwestern Gulf of Mexico. - Contr. mar. Sci. 27, 49-64.

Gerlach, S. A., 1971. On the importance of marine meiofauna for benthos communities. - Oecologia $6,176-190$.

Gerlach, S. A., 1978. Food-chain relationships in subtidal silty sand marine sediments and the role of meiofauna in stimulating bacterial productivity. - Oecologia 33, 55-69.

Gittings, S. R., Bright, T. J. \& Powell, E. N., 1984. Hard-bottom macrofauna of the East Flower Garden brine seep: impact of a long-term, sulfurous brine discharge. - Contr. mar. Sci. 27. $105-125$.

Guille, A. \& Soyer, J., 1968. La faune benthique des substrats meubles de Banyuls-sur-mer premières données qualitatives et quantitatives, - Vie Milieu (B.) 19, 323-360.

Haines, E. B. \& Montague, C. L, 1979. Food sources of estuarine invertebrates analyzed using ${ }^{13} \mathrm{C} /$ ${ }^{12} \mathrm{C}$ ratios. - Ecology $60,48-56$.

Heip, C., Herman, P. M. J. \& Coomans, A., 1982. The productivity of marine meiobenthos. - Meded. K. Acad. Wet. Lett. Schone Kunsten Belg. (KL. Wet. Academiae Analecta) 44, 1-20.

Hoffman, A., 1978. System concepts and the evolution of benthic communities. - Lethaia 11 , 179-183.

Jensen, P., (1986a). The nematode fauna in the sulphide-rich brine seep and adjacent bottoms of the East Flower Garden, NW Gulf of Mexico. 1. Chromadorida. - Zool. Scr. 12 (in press).

Jensen, P., (1986b). The nematode fauna in the sulphide-rich brine seep and adjacent bottoms of the East Flower Garden, NW Gulf of Mexico. II Monhysterida. - Zool. Scr. 12 (in press).

Jensen, P., (1986c). The nematode fauna in the sulphide-rich brine seep and adjacent bottoms of the East Flower Garden, NW Gulf of Mexico. III Enoplida. - Zool. Scr. 12 (in press).

Jørgensen, B. B., 1977. Distribution of colorless sulfur bacteria (Beggiatoa spp.) in a coastal marine sediment. - Mar. Biol. 41, 19-28.

Jørgensen, B. B. \& Revsbech, N. P., 1985. Diffusive boundary layers and the oxygen uptake of sediments and detritus. - Limnol. Oceanogr. 30, 111-122.

Kuipers, B. R., de Wilde, P. A. W. J. \& Cruetzberg, F., 1981. Energy flow in a tidal flat ecosystem.Mar. Ecol. Prog. Ser. 5, 215-221.

Lambshead, P. J. D., 1984. The nematode/copepod ratio some anomalous results from the Firth of Clyde. - Mar. Pollut. Buil. 15, 256-259.

Lauer, R. D., 1979. Sulfur deposition in the East Flower Gardens, Gulf of Mexico. Thesis, Florida State Univ., $33 \mathrm{pp}$.

Levine, S., 1980. Several measures of trophic structure applicable to complex food webs. $-J$. theor. Biol. 83, 195-207.

Levinton, J. 1972. Stability and trophic structure in deposit-feeding and suspension-feeding communities. - Am. Nat. 106, 472-486.

Mackin, J, G., 1973. A review of significant papers on effects of oil spills and oil field brine discharges on marine biotic communities. - Tech. Rep. Centr. Texas A\&M Res. Fdn Proj. 737, $1-87$.

Mare, M. F., 1942. A study of a marine benthic community with special reference to the microorganisms. - J. mar. biol. Ass. U.K. 25, 517-554.

McConnaughey, T. \& McRoy, C. P., 1979. Food-web structure and the fractionation of carbon isotopes in the Bering Sea. - Mar. Biol. 53, 257-262.

McIntyre, A. D., 1961. Quantitative differences in the fauna of boreal mud associations. - J. mar. biol. Ass. U.K. 41, 599-616.

McIntyre, A. D., 1969. Ecology of marine meiobenthos. - Biol. Rev. 44, 245-290.

Montagna, P. A., Coull, B. C, Herring, T. L. \& Dudley, B. W., 1983. The relationship between 
abundances of meiofauna and their suspected microbial food (diatoms and bacteria). - Estuar. coast. Shelf Sci. 17, 381-394.

O'Brien, D. J. \& Birkner, F. B., 1977. Kinetics of oxygenation of reduced sulfur species in aqueous solution. - Environ. Sci. Technol. 11, 1114-1120.

Osmond, C. B., Valaane, N., Haslam, S. M. Uotila, P. \& Roksandic, Z, 1981. Comparison of $\delta^{13} \mathrm{C}$ values in leaves of aquatic macrophytes from different habitats in Britain and Finland: some implications for photosynthetic processes in aquatic plants. - Oecologia 50, 117-124.

Parker, P. L., Behrens, E. W., Calder, J. A. \& Shultz, D. 1972. Stable carbon isotope ratio variations in the organic carbon from Gulf of Mexico sediments. - Contr. mar. Sci. 16, 139-147.

Parker, P. L., Scalan, R. Winters, K. \& Boatwrith, D., 1981. High molecular weight hydrocarbons, delta $\mathrm{C}-13$, and total organic carbon in sediment. - Techn. Rep. Texas A\&M Univ. 81-2-T, $100-114$.

Pearson, T. H. 1981. Stress and catastrophe in marine benthic ecosystems. In: Stress effects on natural ecosystems. Ed. by G. W. Barrett \& R. Rosenberg. Wiley, New York, 201-214.

Pequegnat, W. E. \& Sikora, W. R., 1977. Meiofauna project. In: Environmental studies, south Texas outer continental shelf, biology and chemistry. - Final Rep. U.S. Dept. Interior Bureau Land Management Contract Nr. 08550-CT6-17, 8-1 to 8-57.

Peterson, C. H., 1977. Competitive organization of the soft-bottom macrobenthic communities of southern California lagoons. - Mar. Biol. 4, 343-359.

Peterson, C. H., 1980. Approaches to the study of competition in benthic communities in soft sediments. In: Estuarine perspectives, Ed. by V. S. Kennedy. Acad. Press, New York, 291-302.

Peterson, C. H., 1982. The importance of predation and intra- and interspecific competition in the population biology of two infaunal suspension-feeding bivalves, Protothaca staminea and Chione undatella. - Ecol. Monogr. 52, 437-475.

Peterson, C. H., 1983. Interactions between two infaunal bivalves, Chione undatella (Sowerby) and Protothaca staminea (Conrad), and two potential enemies, Crepidula onyx (Sowerby) and Cancer anthonyi (Rathbun). - J. exp. mar. Biol. Ecol. 68, 145-158.

Powell, E. N. \& Bright, T. J., 1981. A thiobios does exist: gnathostomulid domination of the canyon community at the East Flower Garden brine seep. - Int. Revue. ges. Hydrobiol. 66, 675-683.

Powell, E. N., Bright, T. J., Woods, A. \& Gittings, S., 1983. Meiofauna and the thiobios in the East Flower Garden brine seep. - Mar. Biol. 73, 269-283.

Raffaelli, D. G., 1981. Monitoring with meiofauna - a reply to Coull, Hicks and Wells (1981) and additional data. - Mar. Pollut. Bull. 12, 381-382.

Raffaelli, D. G. \& Mason, C. F., 1981. Pollution monitoring with meiofauna, using the ratio of nematodes to copepods. - Mar. Pollut. Bull. 12, 158-163.

Rau, G. H., Mearns, A. J., Young, D. R., Olson, R. J., Schafer, H. A. \& Kaplan, I. R., 1983. Animal ${ }^{13}$ C $/$ ${ }^{12} \mathrm{C}$ correlates with trophic level in pelagic food webs. - Ecology $64,1314-1318$.

Reise, K., 1977. Predator exclusion experiments in an intertidal mud flat. - Helgoländer wiss. Meeresunters. 30, 263-271.

Reise, K., 1979. Moderate predation on meiofauna by the macrobenthos of the Wadden Sea. Helgoländer wiss. Meeresunters. 32, 453-465.

Renaud-Mornant, J. C., Salvat, B. \& Bossy, C., 1971. Macrobenthos and meiobenthos from the closed lagoon of a Polynesian atoll, Maturei Vavao (Tuamotu). - Biotropica 3, 36-55.

Round, F. E., 1979. A diatom assemblage living below the surface of intertidal sand flats. - Mar. Biol. 54, 219-223.

Sackett, W. M., Nakaparskin, S. \& Dalrymple, D., 1970. Carbon isotope effects in methane production by thermal cracking. - Adv. org. Geochem. 1966, 37-53.

Sanders, H. L., 1960. Benthic studies in Buzzards Bay III. the structure of the soft-bottom community. - Limnol. Oceanogr. 5, 138-153.

Schidlowski, M., Matzigkeit, U. \& Krumbein, W. E., 1984. Superheavy organic carbon from hypersaline microbial mats assimilatory pathway and geochemical implications. - Naturwissenschaften 71, 303-308.

Sofer, Z., 1984. Stable carbon isotope compositions of crude oils: application to source depositional environments and petroleum alteration, - Bull. Am. Ass. Petrol. Geol. 68, 31-49.

Spies, R. B. \& Davis, P. H., 1979. The infaunal benthos of a natural oil seep in the Santa Barbara Channel. - Mar. Biol. 50, 227-237. 
Stein, J. L., 1984. Subtidal gastropods consume sulfur-oxidizing bacteria: evidence from coastal hydrothermal vents. - Science, N.Y. 223, 696-698.

Straughan, D., 1982. Observations on the effects of natural oil seeps in the Coal Oil Point area. Phil. Trans. R. Soc. Lond. (B) 297, 269-283.

Tenore, K. R., 1983. Organic nitrogen and caloric content of detritus III. Effect on growth of a deposit feeding polychaete Capitella capitata. - Estuar, coast. Shelf Sci. 17, 733-742.

Thayer, G. W., Govoni, J. J. \& Connelly, D. W., 1983. Stable carbon isotope ratios of the planktonic food web in the northern Gulf of Mexico. - Bull. mar. Sci. 33, 247-256.

Thomassin, B. A. Vivier, M. \& Vitiello, P., 1976. Distribution de la meiofaune et de la macrofaune des sables coralliens de la retenue d'eau epirécifale du Grand Récif de Tuléar (Madagascar). - J. exp. mar. Biol. Ecol. 22, 31-53.

Thomassin, B. A., Jouin, C., Renaud-Mornant, J., Richard, G. \& Salvat, B., 1982. Macrofauna and meiofauna in the coral sediments on the Tiahura reef complex, Moorea Island (French Polynesia). - Tethys 10, 392-397.

Virnstein, R. W., 1977. The importance of predation by crabs and fishes on benthic infauna in Chesapeake Bay. - Ecology 58, 1199-1217.

Virnstein, R. W., 1979. Predation on estuarine infauna: response patterns of component species, Estuaries 2,69-86.

Wangersky, P. J. \& Wangersky, C. P., 1981. The manna effect: the structure of benthic populations, Int. Revue ges. Hydrobiol. 66, 777-786.

Warwick, R. M, 1984. Species size distributions in marine benthic communities, - Oecologia 61 , $32-41$.

Wieser, W., 1960. Benthic studies in Buzzards Bay II. The meiofauna. - Limnol. Oceanogr. 5 , $121-137$

Wigley, R. L. \& McIntyre, A. D., 1964. Some quantitative comparisons of offshore meiobenthos and macrobenthos south of Martha's Vineyard. - Limnol. Oceanogr. 9, 485-493.

Wiltse, W. I., Foreman, K. H., Teal, J. M. \& Valiela, I., 1984. Effects of predators and food resources on the macrobenthos of salt marsh creeks. - J. mar. Res. 42, 923-942.

Witte, J. I. \& Zijlstra, J. J., 1984. The meiofauna of a tidal flat in the western part of the Wadden Sea and its role in the benthic ecosystem. - Mar. Ecol. Prog. Ser. 14, 129-138.

Wong, W., Sackett, W. M. \& Benedict, C. R., 1975. Isotope fractionation in photosynthetic bacteria during carbon dioxide assimilation. - Pl. Physiol. 55, 475-479.

Yingst, J. Y. \& Rhoads, D. C., 1985. The structure of soft-bottom benthic communities in the vicinity of the Texas Flower Garden Banks, Gulf of Mexico. - Estuar. coast. Shelf Sci. 20, 569-592.

Young, D. K. \& Young, W. M., 1978. Regulation of species densities of seagrass-associated macrobenthos: evidence from field experiments in the Indian river estuary, Florida. - J. mar. Res. 36, 569-593. 